AGH DRILLING, OIL, GAS • Vol. 32 • No. $1 \cdot 2015$

http://dx.doi.org/10.7494/drill.2015.32.1.23

\author{
Szymon Kuczyński*, Dominik H. Skokowski*, \\ Tomasz Wlodek*, Krzysztof Polański*
}

\title{
COMPRESSED AIR ENERGY STORAGE AS BACKUP GENERATION CAPACITY \\ COMBINED WITH WIND ENERGY SECTOR IN POLAND - IMPLEMENTATION POSSIBILITIES**
}

\section{INTRODUCTION}

Wind energy development is an element of sustainable growth, which puts emphasis not only on the environmental gains, but also economic and social ones. The wind energy industry is now one of the most dynamically developing branches of renewable energy sector. Global installed wind power capacity totaled 318105 MW in 2013. Just between 2008 and 2013 worldwide power capacity increased by $200000 \mathrm{MW}$. The main centers of growth are China, USA and European Union countries, chiefly Germany and Spain [1].

In recent years Poland also experienced rapid development of renewable energy sector - 25.5\% between 2012 and 2013 [2] - including domestic wind energy. Up until now 890 wind turbines have been constructed amounting for $3727 \mathrm{MW}$ of installed wind power capacity, which constitutes $63 \%$ of renewable energy sector in Poland [2]. The most promising areas for development of wind farms are located along the Baltic Sea shore and in the central Poland (see Fig. 1).

However, wind energy is characterized with some flaws. One of the most significant is the unpredictability of electricity production due to wind strength variations [4]. Combined with the limited capabilities of storing electricity there is a serious issue of flexibility of the grid, which cannot respond to the daily and seasonal fluctuations in demand (low during the night and high in daytime). With increased wind energy penetration on the grid there comes a problem of the whole energy system's ability to adjust to the supply and demand.

* AGH University of Science and Technology, Faculty of Drilling, Oil and Gas, Krakow, Poland, polanski@agh.edu.pl

** This paper is a part of statutory research program (11.11.190.555/2015) performed at the AGH University of Science and Technology (Faculty of Drilling, Oil and Gas) 


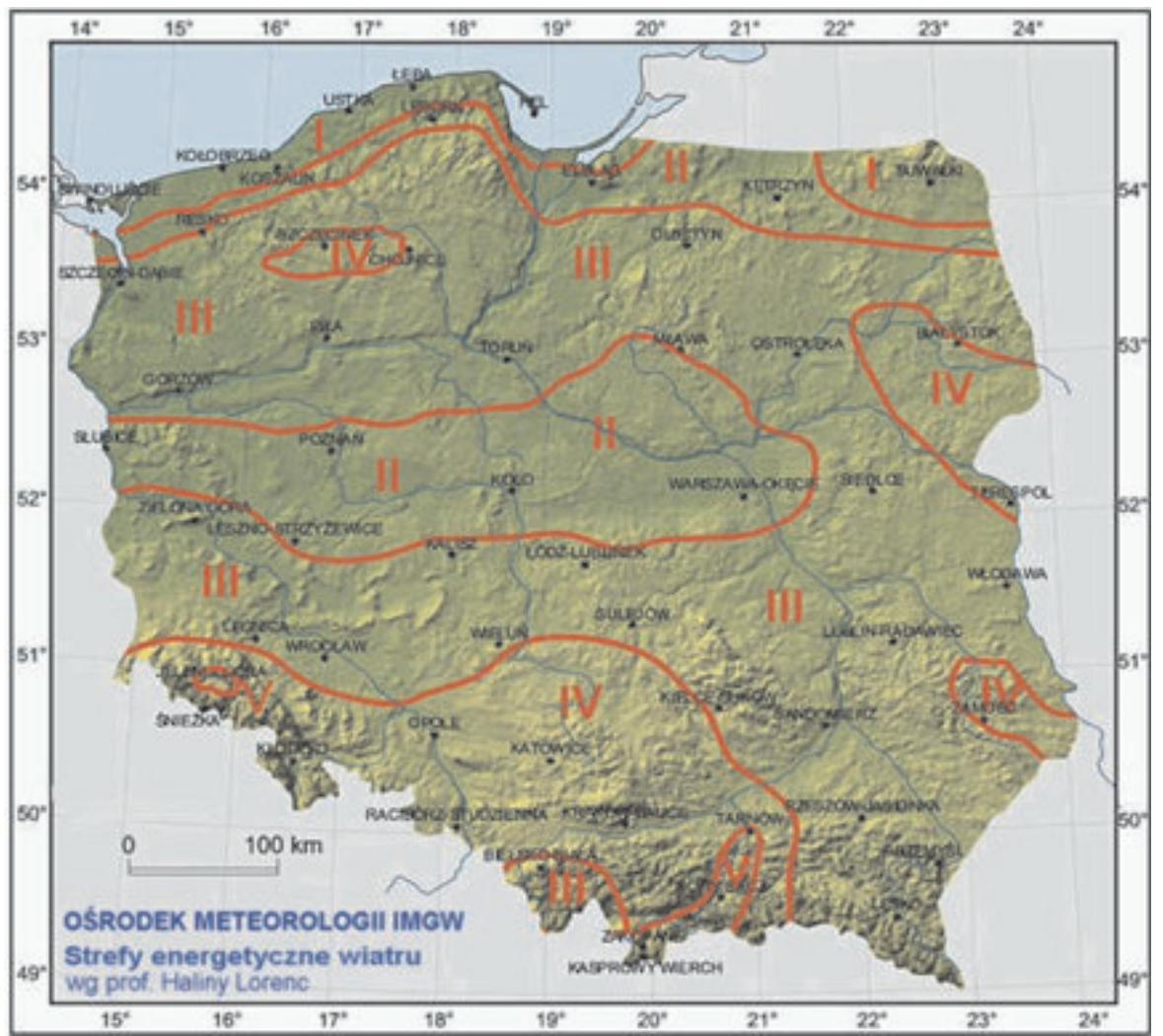

Fig. 1. Poland's wind resources ( 1 - extraordinarily favorable, II - very favorable, III - favorable, IV - poorly favorable, V - unfavorable) [5]

The principal electricity storage technologies include hydropower with storage, compressed air energy storage, flow batteries, hydrogen-based energy systems, secondary batteries, flywheels, super capacitors, and superconducting magnetic energy storage. Different types of electricity storage vary substantially in terms of functioning and storage capacity. Pumped hydro and CAES are characterized by relatively large amounts of installed power capacity possible to obtain, in range of 255-1130 MW for the former, and 110-290 WM for the latter, however there are 2500 MW CAES projects being considered, as in case of Norton project in USA. For chemical batteries and flywheels, the range is, respectively, between 1-32 MW and 1-20 MW [6].

Chemical batteries and flywheels cannot store large amounts of energy, therefore they are not suited for integration with large-scale generation facilities. On the other hand, pumped hydro energy storage has serious limitations due to geography and its potential has already been utilized in most of developed countries.

CAES technology is currently one of the most promising solutions to the instability of the grid regarding the range of installed power capacity as well as lesser geographical 
constraints than pumped hydro [22]. Considering the basic characteristics of wind energy intermittency and unpredictability the CAES technology is a natural choice to compensate these deficits. The existing CAES plant in Huntorf is already working with the renewable energy sector in Germany and feasibility studies of similar projects have been conducted, e.g. NYSERDA project for New York State [13].

\section{CAES PLANT FUNCTIONING MECHANISM}

There are only two CAES plants currently functioning in the world. The first one was constructed in 1978 in Huntorf in the North Germany, the second one was built in 1991 in McIntosh, Alabama, USA. The idea behind CAES technology was storing electricity produced by nuclear (Huntorf [7]) or coal plants (McIntosh [8]) during hours of low demand and feeding it back to the grid during period of high demand, as well as providing the black-start power for those facilities. Along with the development of the wind energy sector in Germany the Huntorf plant was retrofitted to operate with the wind turbines.

In CAES plant mechanical energy is transformed into the potential energy of compressed air and in the reverse cycle, back into mechanical energy [9]. The air is stored in an underground storage. In the existing facilities salt caverns were used for this purpose, but theoretically there are other possibilities, e.g. using decommissioned mine shafts or aquifers [7].

In the simplest CAES system, as implemented in Huntorf plant, air is compressed during the hours of low demand and therefore, low electricity prices, then it is stored in two salt caverns located at depth of 650-800 meters below the surface (Fig. 2). During the time of high demand air is drawn from the underground storage and used to burn natural gas. After the combustion the mixture is allowed to expand in two-stage turbine, thus producing electricity. The installed power capacity of the plant reaches $290 \mathrm{MW}$ with cycle efficiency of $42 \%$. The electricity generation system is almost identical as in the regular gas turbine. The advantage of CAES plant is the supply of compressed air stored and ready to use, whereas a regular gas turbine uses approximately $2 / 3$ of its power to compress air [7]. It accounts for $60-70 \%$ reduction of greenhouse gases emissions compared to the natural gas plant. Furthermore, in regular natural gas facility there is a problem of efficiency falling by $10 \%$ every $5^{\circ} \mathrm{C}$ increase in temperature due to the decreasing air density. This problem doesn't apply to the CAES plant owing to the availability of compressed air already stored in the caverns [10].

McIntosh CAES plant was built in 1991 and was based on the Huntorf CAES facility. The major modification was implementation of heat recuperator. The idea is to use high temperature exhaust gases to heat compressed air before it enters the combustion chamber [11]. In this case the efficiency increases to $56 \%$ [12] while the fuel consumption drops by $25 \%$ [13]. McIntosh plant has the installed power capacity of $110 \mathrm{MW}$. 


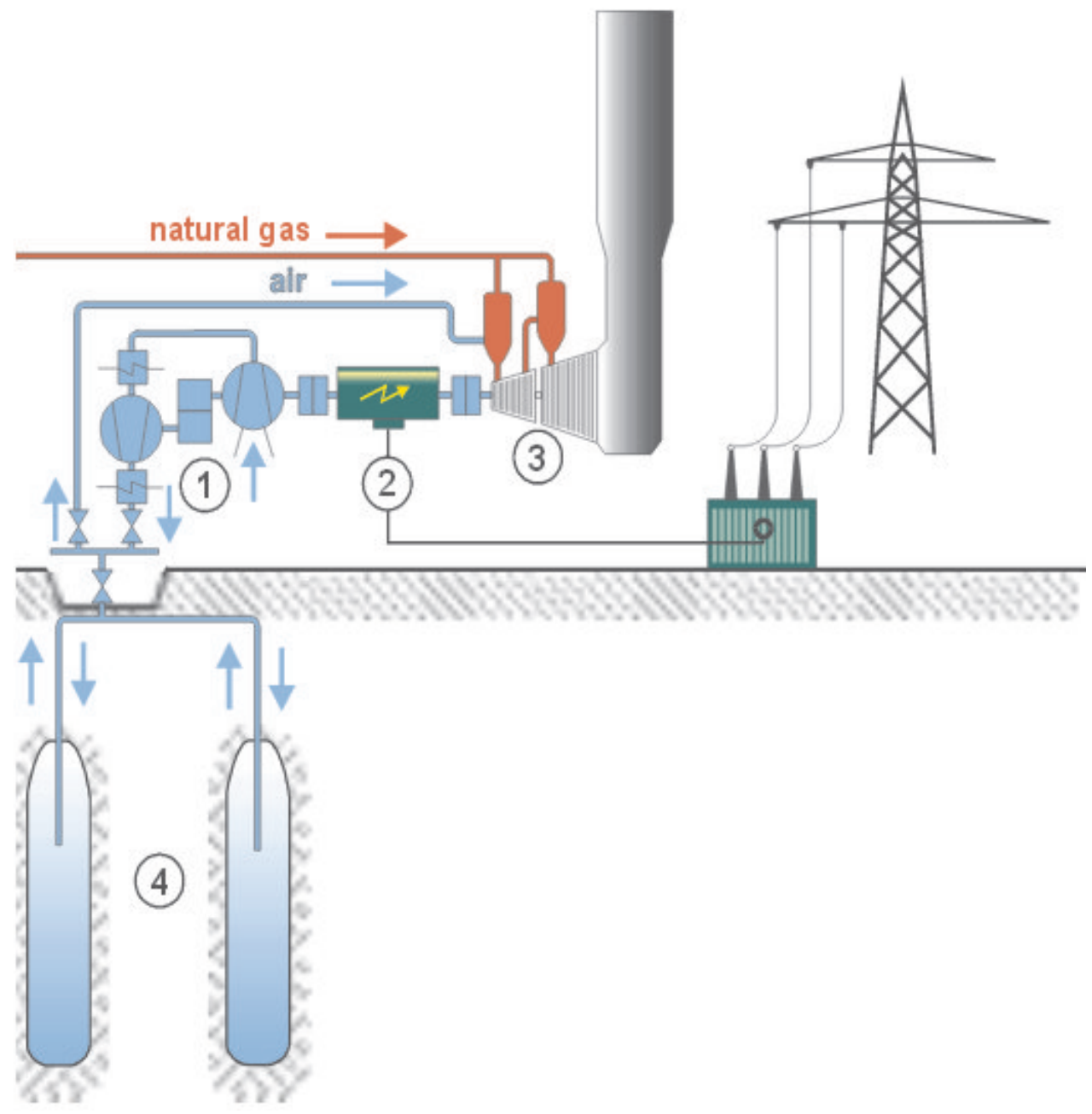

Fig. 2. Huntorf CAES scheme (1 - compressor, 2 - generator, 3 - gas turbine, 4 - salt caverns) [7]

Since the commissioning of McIntosh plant the CAES technology has undergone dynamic development and various modifications have been proposed to increase its efficiency. One of the most crucial is adiabatic process of compression and expansion of air in CAES plant, so-called AA-CAES (Advanced Adiabatic CAES) (Fig. 3). This kind of facility differs substantially from its predecessors. The key element is thermal energy storage. Thermal energy is captured during air compression and used to heat it up in the process of expansion. Warm air is sent through turbine, thus generating electricity. This innovation increases the efficiency of the process (to over $70 \%$ ) as well as eliminates the need for natural gas combustion, therefore reducing the greenhouse emissions to $0 \%$ [14]. 


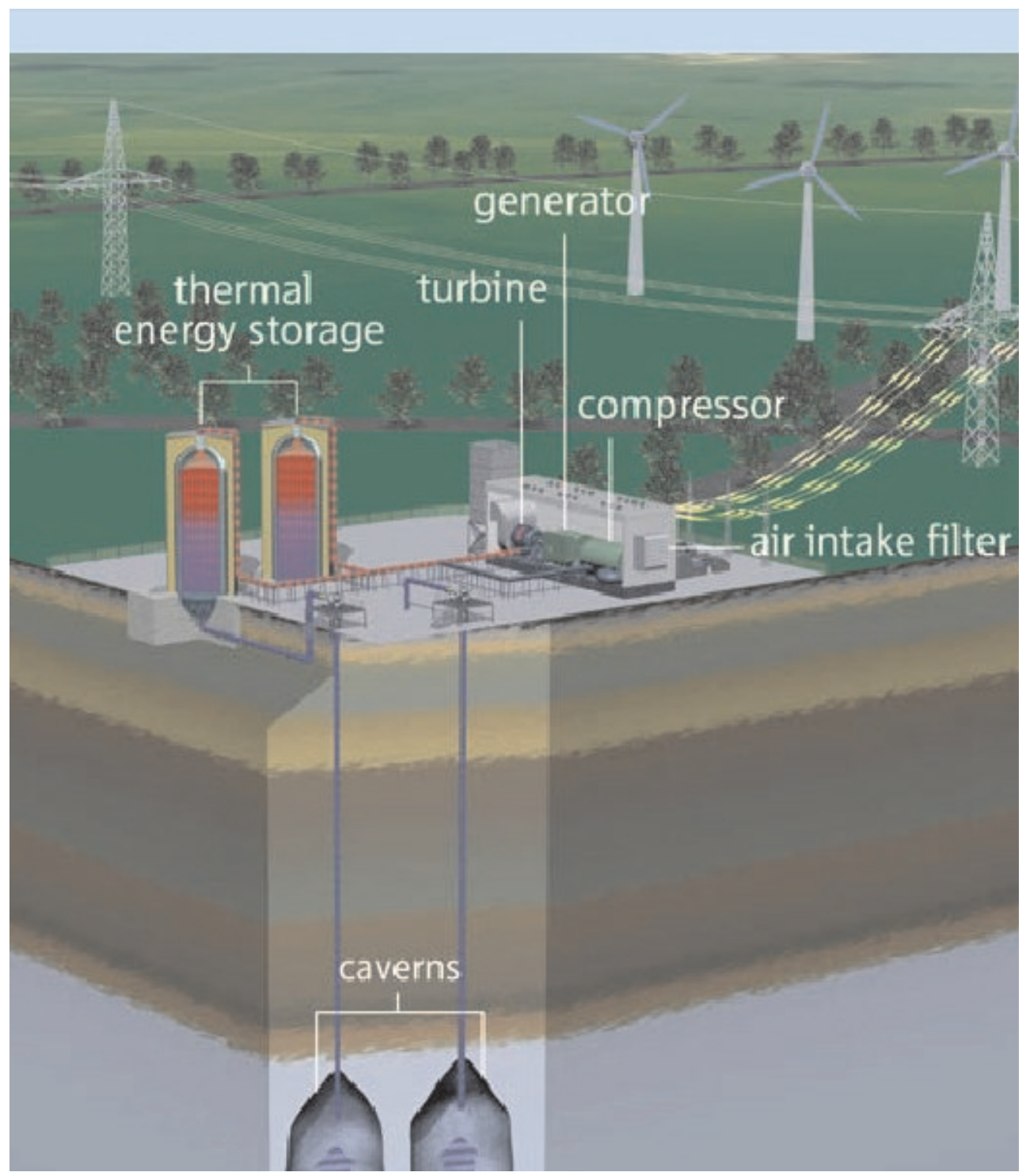

Fig. 3. Advanced Adiabatic-CAES plant scheme [24]

The isothermal process of air compression is also being developed. In this case the volume and pressure parameters are strictly controlled so the $\mathrm{p}-\mathrm{V}$ curve during the compression and expansion phases resemble anisotherm. The mechanism eliminates the need for heating fuel as compared to the traditional CAES plant, as well as the need for the thermal energy storage as in AA-CAES. The process takes place in conditions of very slow pressure changes and efficient heat exchange with the environment [15]. 
A design of CAES plant substituting coal for natural gas as the fuel has been proposed [25]. Its main advantage is applicability in countries rich in coal, but scarce in natural gas, e.g. Chins. While still using coal, this approach makes gradual shift away from coal plants towards renewables.

There are also different CAES technologies in the research phase, e.g. micro-CAES, isobaric CAES or combination of pumped hydroelectric storage with CAES plant [15]. The key characteristics of innovative CAES concepts is an attempt to correct the flaws of Huntorf and McIntosh plants, i.e. low efficiency and necessity of fuel combustion.

\section{ECONOMICAL ASPECTS OF CAES}

CAES technology is ideally suited for compensating for the energy deficits in the grid, as well as economically utilize the surplus power resulting from unpredictability of wind. The economic rationale of the plant is to buy cheap energy during the hours of low demand (at night) and feeding it back to the grid during high demand (during daytime). An example of a working day of CAES facility is pictured in Figure 4.

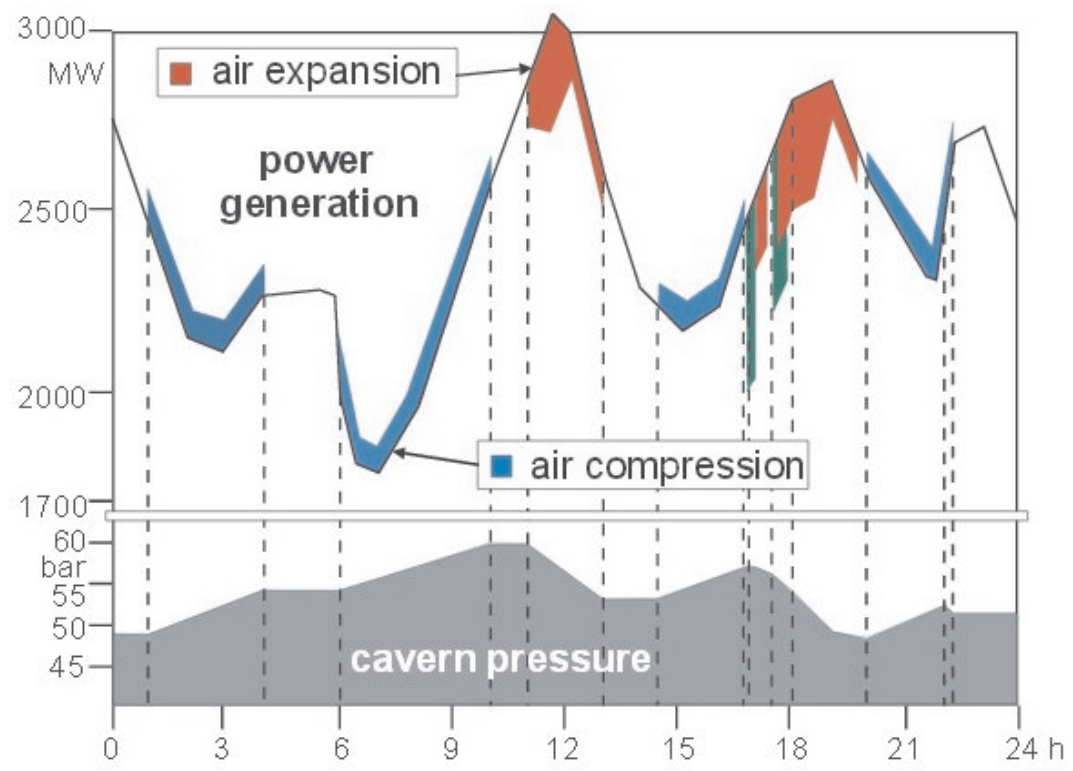

Fig. 4. Example of working day of the CAES plant [7]

CAES plant can be turn on and off accordingly to the needs of the grid. Time which is required from the start to reach full capacity is only several minutes. For comparison, coal plant reaches maximum capacity within 3 to 4 hours [7]. It translates directly to increase in local energy security level. 
In case of facilities providing backup power, e.g. power plant compensating for the insufficiencies of the wind farms, investment cost per installed power capacity unit becomes a relevant economic factor. Regarding this aspect, the CAES technology has high potential of implementation in the energy sector [16]. Estimation of construction costs for CAES plants bear high possibility of error due to the scarcity of data (there have been only two CAES plants in the world). Possible costs and requirements depend heavily on local features such as geological structure. The important factor is whether leaching the salt cavern is included in the budget, or rather an existing structure is supposed to be used. Leaching a single cavern for the requirements of the 135 MW CAES plant amounts for \$15 to $\$ 20$ million [4]. Feasibility study on the possibility of integrating CAES with wind energy sector in the state of New York has found that investment expenditure per installed power capacity unit necessary for the new plant varies between $\$ 397$ and $\$ 1001$ per $\mathrm{kW}$ depending on the technological option [13].

Beside the economic aspects of construction, there are also operating expenditures that need to be taken into account, namely the optimization of buying and selling procedure. The mathematical algorithm would have to combine analysis of market fluctuations with meteorological data regarding the speed of wind. It is also relevant whether the market transactions would take place on the intra-day or day-ahead market [17].

\section{CAES - POSSIBILITIES OF IMPLEMENTATION IN POLAND}

Pumped hydroelectric storage facilities exist currently in Poland to provide the backup energy in case of wind farm insufficiencies. There are six such facilities of combined installed power capacity reaching $1.7 \mathrm{GW}$ [18]. However, as research suggests [19], there are prospects for implementing the CAES technology in Poland as an alternative to the pumped hydro.

Identification of construction site is one of the crucial steps in planning a CAES plant. It has to be located in a favorable wind energy zone and above a geological salt structure of proper characteristics. There are areas in Poland meeting both criterions (Fig. 5). These are, among others, areas of Gdansk Bay (Zatoka Gdańska), with salt caverns $200 \mathrm{~m}$ thick and roof levels 600 to $900 \mathrm{~m}$ below the ground, and Goleniów region (North-West Poland), where suitable salt formations exist at the depth of $900 \mathrm{~m}$. Favorable location can be found in Central Poland, where salt structures exist 105 to $475 \mathrm{~m}$ below the ground [20].

Areas in the vicinity of existing underground gas storage facilities are preferable for the construction of the CAES plant in Poland, e.g. near Mogilno and Kosakowo. However, the CAES plant is more complicated to build than an underground gas storage facility [20].

A relevant condition of success of the CAES technology in Poland is green certificates mechanism. A traditional CAES plant requires natural gas to propel the turbine and produce electricity. This could cause a loss of some green certificates of the wind energy thus reducing the competitiveness of electricity produced by CAES on the market [23]. A solution to this problem is application of the innovative CAES that don't require fossil fuels, e.g. advanced adiabatic CAES or isothermal CAES. 


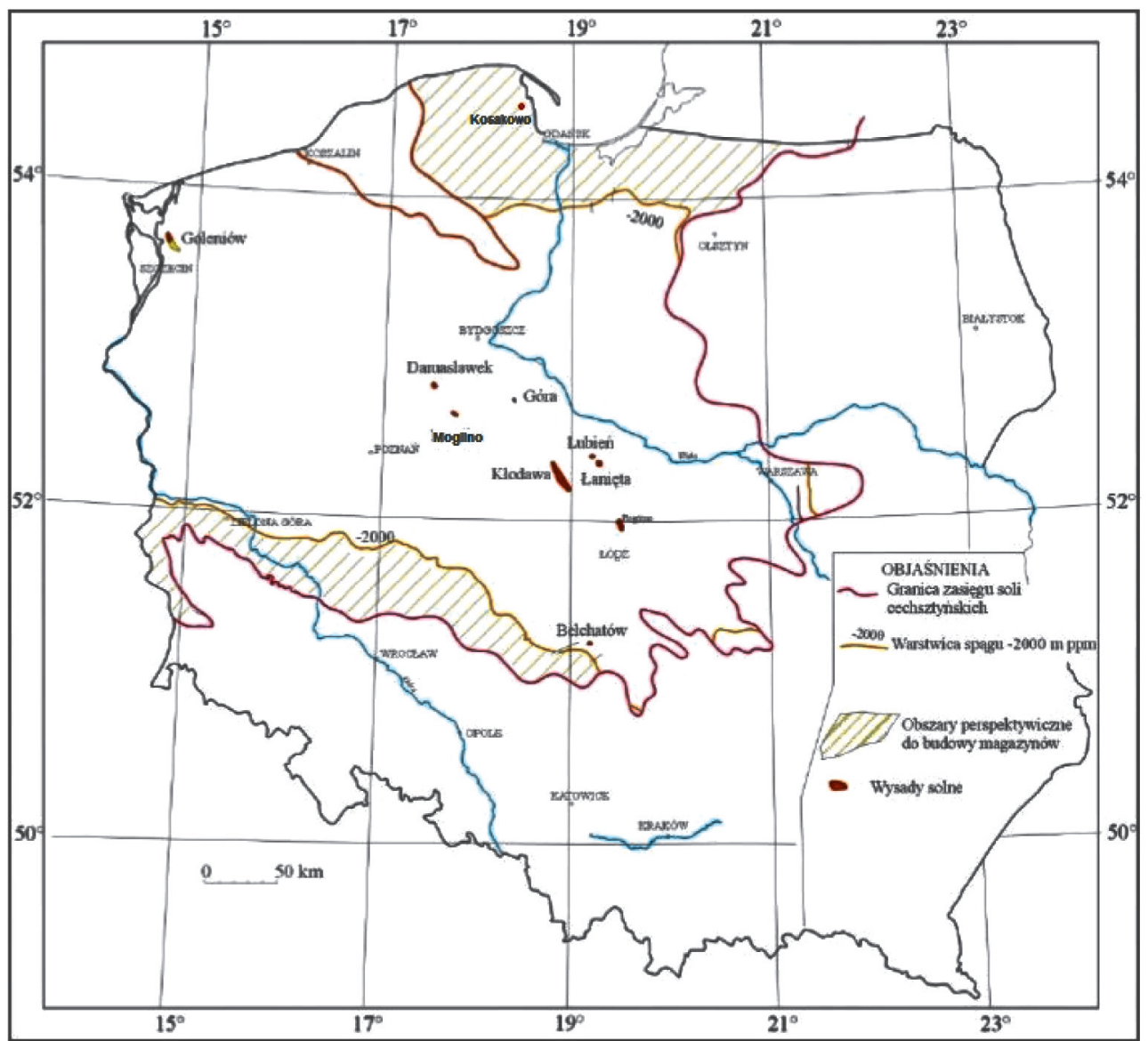

Fig. 5. Geological salt formations in Poland with perspective areas for underground gas storage facilities construction highlighted [21]

\section{CONCLUSIONS}

Despite technological maturity, CAES has never been widely implemented. However, the number of research papers and reports on compressed air energy storage being published every year indicate, that this technology is still being developed. Current state of knowledge allows to build CAES plants far exceeding the efficiencies of existing facilities from 1970s and 90s, as well as to eliminate the need for fossil fuels. Various CAES projects of different installed power capacities are considered in many countries, e.g. USA, Canada, Ireland, Israel, Germany, Luxembourg and China. Furthermore, USA and China are developing national research programs focused on CAES technology. All this scientific and industrial activity allows to presume the high potential of this particular energy storage method. 
Construction of CAES plant in Poland could face many obstacles and requires a lot of research and analysis before feasibility of such a project could be determined. However, current state of knowledge indicate, that both geological conditions (suitable salt formations at proper depth) as well as wind resources (favorable wind zones) are promising for potential implementation of CAES technology in this country. Definitive advantage of its application would be decrease in the negative effects of wind energy unreliability and unpredictability, which would translate into increase in the energy security.

However, there are risks, such as difficulty of optimization of buying and selling mechanism that pose a threat to the commercial success of CAES plant on the market. A potential loss of green certificates is also a factor to be considered in the basic scenario (CAES fueled by natural gas).

\section{REFERENCES}

[1] Global Wind Energy Council: Global Wind Report Annual Market Update. 2013.

[2] BP Statistical Review of World Energy. 2014.

[3] Urząd Regulacji Energetyki: ure.gov.pl, access: 25.08.2014.

[4] Kepplinger J., Crotogino F., Donadei S.: Present Trends in Compressed Air Energy and Hydrogen Storage in Germany. SMRI Fall 2001 Technical Conference 3-4 October 2011.

[5] Ośrodek Meteorologii IMGW.

[6] PacifiCorp: Energy Storage Screening Study For Integrating Variable Energy Resources within the PacifiCorp System. 2011.

[7] Crotogino F., Mohmeyer K.-U., Scharf R.: Huntorf CAES / More than 20 years of successful operation. 2001.

[8] Dresser-Rand: Compressed Air Energy Storage (CAES). 2010.

[9] Dzierżanowski Ł.: Elektrownie CAES. 2011.

[10] Connolly D.: A Review of Energy Storage Technologies: For the integration of fluctuating renewable energy. 2010.

[11] Mason J.E., Archer C.L.: Baseload electricity from wind via compressed air energy storage (CAES). 2012.

[12] Elmegaard B., Brix W.: Efficiency of Compressed Air Energy Storage. 2011.

[13] NYSERDA: Compressed Air Energy Storage Engineering and Economic Study, Final report. 2009.

[14] Zunft S., Jakiel C., Koller M., Bullough C.: Adiabatic Compressed Air Energy Storage for the Grid Integration of Wind Power. 2006.

[15] Kim Y.M., Lee J.H., Kim S.J., Favrat D.: Potential and Evolution of Compressed Air Energy Storage: Energy and Exergy Analyses. 2012.

[16] Madlener R., Latz J.: Centralized and Decentralized Compressed Air Energy Storage for Enhanced Grid Integration of Wind Power. 2009. 
[17] Gu Y., McCalley J., Ni M., Bo R.: Economic Modeling of Compressed Air Energy Storage. 2013.

[18] Adamska B.: Elektrownie szczytowo-pompowe, ponad 100-letnia technologia szansq na przyszłość. 2013.

[19] Radziewicz W.: System magazynowania energii CAES a energetyka wiatrowa. 2011.

[20] Nagy S., Polański K., Ślizowski J.: The Possibility of Applying CAES Technology in Polish Conditions. 2014.

[21] Ślizowski J., Lankof L., Wojtuszewska K.: Geomechaniczna ocena optymalnej gtębokości komór magazynowych gazu ziemnego w polskich złożach soli kamiennej. 2007.

[22] Bullough C., Gatzen C., Jakiel C., Koller M., Nowi A., Zunft S.: Advanced Adiabatic Compressed Air Energy Storage for the Integration of Wind Energy. 2004.

[23] Badyda K., Milewski J.: Elektrownie CAES - możliwości akumulacji energii oraz wspótpracy ze źródtami odnawialnymi. 2010.

[24] RWE: ADELE - Adiabatic Compressed-Air Energy Storage For Electricity Supply. 2010.

[25] Liu W., Yang Y., Zhang W., Xu G., Wu Y.: A Novel hybrid-fuel Compressed Air Energy Storage System for China's Situation. 2012. 